\title{
Alternative fish feed production from waste chicken feathers
}

\author{
Sri Jumini \\ Physics Department Sains AlQuran University, \\ Jl. Raya Kalibeber, Km. 03 Mojotengah Wonosobo Jawa Tengah, INDONESIA \\ E-mail: umy fadhil@yahoo.com
}

\begin{abstract}
In this This devotion has been done to provide education and training of the utilization of waste chicken manure, making flour chicken feathers as a fish feed alternative, that can overcome some of the problems that waste chicken feathers from the center cutting broiler chickens in the village Krasak enough, it causes pollution, and not used optimally; Low public awareness of awareness of environmental pollution; the lack of public knowledge about the utilization of waste chicken feathers, and processing technology, as well as to address the needs of fish feed more expensive, need alternative feed ingredients. This service program has provided insight to the public about waste chicken feathers so that it can be used as a new entrepreneurial startups. To achieve these objectives have been done of activity as follows: 1) Provide counseling and understanding of the community will be a negative impact on the environment of waste chicken feathers. 2) Provide counseling utilization of waste chicken feathers for people in nearby farms. 3) Make a chicken feather meal of chicken feather waste as an alternative fish feed to improve digestibility of chicken feathers. 3) The formation of the group for increasing the economic income of the family. This service activities program runs quite well with demonstrated some activity, namely: 1) Change Behavior Society (knowledge transfer); 2) Chicken Feather Extension Waste Utilization; 3) Making Unit Waste Chicken Feathers; 4) Establishment of New Business of Diversified Waste Chicken Feathers.
\end{abstract}

\section{Introduction}

The village is a Wonosobo Mojotengah Krasak District of central broiler cuts in the district. Wonosobo. People in this area most of livelihood as a trader, and a small portion of employees, employers and self-employed. This cutting centers have a social impact that is good for the community because it can empower people around it so minimal to reduce the number of unemployed in the village Krasak. The workers in the slaughterhouse broiler mostly young men for work starting at 1:00 pm until the morning. Furthermore, chicken meat directly sold into the market by the middlemen.

Unwittingly waste from the slaughterhouse that merchant may cause unfavorable impact on the environment, especially water. This is due to the lack of waste utilization even largely thrown into the river. The severity of the life pattern of dumping waste into the river has become a habit that lasted until now. It is certain that the water quality of the river in the village Krasak very low is indicated by the color of the water is black, odorless, and many jasat-organisms that thrive in polluted rivers such waste (figure 1). 


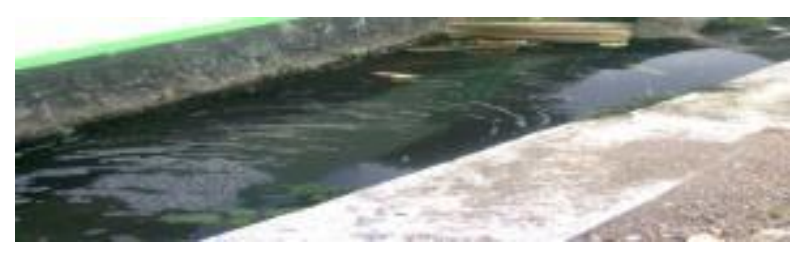

Figure.1. Slaughterhouse waste

Behavior like this is certainly result in pollution, air, soil and water, especially in the morning around 8:00 to 11:00 pm. Air pollution is indicated with a pungent odor that is felt at all. The smell caused by solid waste and liquid waste, rotting in the water of the river, of course, can cause respiratory problems. Handling the pollution problem becomes very important in relation to sustainable development should primarily be offset by the pollution control technology that is appropriate [1].

Water pollution will cause health problems skin. Discharge of wastewater (effluent) that contain high nutrients into the water will cause eutrophication and threaten aquatic ecosystems. To prevent that, the necessary means so that the composition of suspended organic solids can be reduced [2]. Unfortunately villagers Krasak Middle Mojo is still very poor care of the environment and even the condition of the river water is black and smells seem to be considered a matter of course. This condition is possible because the educational level of rural communities Krasak average just graduated from high school in addition to a pattern that has been handed down. The lack of knowledge about waste processing animal waste and high costs of waste treatment makes communities are forced to take a negative solution in addressing the issue.

Cutting waste in the form of chicken entrails, blood, fat, feathers, and water her laundry. The waste can act as a medium for microbial growth and development, so that the waste is decomposing [3]. Decomposing waste could become a hotbed of disease, and the effect could spread disease, such as itching and so on. Thereby cutting waste handling chicken meat needs to be done immediately. However it was to change the mindset of the people is not an easy thing, need times gradual and intensive.

This erroneous lifestyle must be changed by processing the solid waste such as chicken feathers and chicken manure effluent that into a product that can provide great benefits for the environment. Improvement in the quality of waste generated through waste treatment processes are systematically [4]. Through literature studies have proven that chicken feather content of high nutritional value for livestock. Utilization of waste chicken feathers as animal feed is expected to benefit not only financially but more importantly tackling environmental pollution. In fact, it turns chicken feathers can also be used as fish feed. If the utilization of waste can be done optimally it will manifest a culture of healthy living, especially for people in the village Krasak.

In terms of religion also requires each people to keep the environment clean. All forms of good resources that exist on the ground, water, nor air is a boon for the entire creature creations [6]. For that man should be grateful, in one of which the conservation of natural resources from the damage and destruction, as well as maintain and manage them as well as possible. Included in this waste waste that pollute the environment 
feathers so can be used to process them into the waste chicken feathers so it can be beneficial to the environment itself.

On the other hand the need for livestock feed is high. One obstacle to the development of sheep in Indonesia, fluctuations in availability and low quality of feed [7]. Feed in tropical areas are rarely able to meet all the nutritional needs of cattle To overcome this problem need to find new sources of feed which has potential as a livestock feed. Plantation and factory waste can be used as an alternative feed and till now has not been fully utilized.

To grow optimally require livestock feed supplement containing nutrients and high economic value such as soybean meal, fish meal, corn, wheat byproducts / polar and some additional feed such as minerals and vitamins. Most of these materials are imported at considerable cost. By arena, it is necessary alternative to the provision and use of local feed ingredients optimally. One of the byproducts that are available in large quantities and have not been optimally utilized as feed ingredients are chicken feather/poultry. Quill potential to be used as a source of feed protein alternative to conventional protein sources such as soybean meal and fish meal. The feathers can also be used to feed livestock (ruminants, non-ruminants and poultry). Cut the number of chickens increased from year to year so chicken feather be produced also increased and at the same time cause problems if not managed properly.

In relation to the problems faced by the residents Krasak Mojotengah, Team Community Service program of the University of Science Quran in Wonosobo, Central Java has helped find solutions that provide counseling and training waste recycling chicken manure, chicken feathers to make flour as an alternative fish feed. To that end, this service program has been conducted to determine the effectiveness of chicken feather meal as an alternative to fish feed, and have been socialized chicken feather flour products to the public so that it can be used as a new entrepreneurial startups.

\section{Methods of Implementation}

\subsection{Kerangka Framework Troubleshooting}

Based on situation analysis study, partner problems and a target output given the problem-solving solutions intensive training to the utilization of waste chicken feathers Krasak and surrounding communities. The activities carried out include:

1) Explanation of the impact of waste chicken feathers.

2) An explanation of the benefits of chicken feathers to fish.

3) Simulation waste processing chicken feathers.

4) The practice of waste processing chicken feathers.

5) Practice chicken feather waste processing in large quantities.

\subsection{Realization Problem solving}

Implementation of community service in the form of intensive training on the manufacture / processing of waste chicken feathers into feather meal of chicken as a food fish Subdistrict Mojotengah alternative Krasak village, Wonosobo regency, which 
will be implemented through three stages: preparation, implementation, and evaluation / monitoring. The details of the activities carried out are:

1) The preparation stage, include:

(a) Licensing and timing of the implementation of the community Krasak, Mojotengah.

(b) Preparation of papers and best practice guidelines so that the participants can perform activities easily and smoothly.

2) Implementation Phase

Community service will be implemented in four sessions, namely:

(a) Submission of materials which include: waste chicken feathers, chicken feathers and utilization of waste as an alternative fish feed ingredients.

(b) Chicken feather waste processing practices as an alternative fish feed ingredients.

(c) Chicken feather waste processing practices as alternative fish feed ingredients in large quantities.

(d) Consulting and product evaluation chicken feather meal.

3) Phase Monitoring

Monitoring conducted by TIM Community Service UNSIQ Central Java in Wonosobo.

\section{Results and Discussion}

Program community service activities is carried out through four stages of major events in the form of seminars and workshops. Prior to the seminar and workshop event was started with the training of five village cadres on how to utilize the waste chicken feathers, so as to reduce waste chicken feathers in the village Krasak. Kader is used as a pioneering activity before practice to another village cadres. Program activities can be explained as follows:

a. Provide education and understanding of the communities around the cutting chicken on litter, waste and dangers.

Event runs pretty good with indicated the presence of the communities where cutting follows the extension activities were held, with the attendance percentage of $90 \%$ of plan participants. Of the 50 targeted participants who attended 42 participants consisting of community leaders, including devices, village cadres, and the owner of cutting which is the main target. Besides the success of these activities is shown by communities begin to respond and carry out preventive measures against the negative impact of a dirty environment. Chicken feather waste from cutting the original is discharged directly into the pond and pollute waterways society, now accommodated containers provided by a team of devotion to be taken and processed into chicken feather meal, seen the drains not black as drains before this service program there.

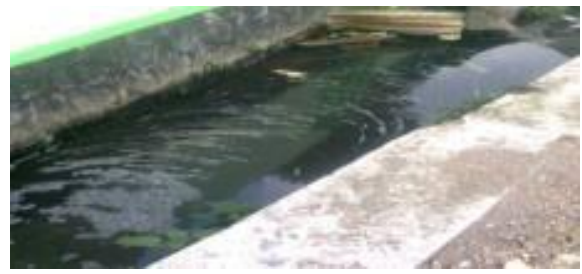

Figure 2. drains before the program

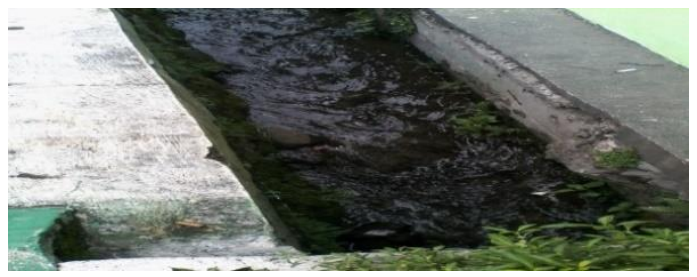

Figure 3. drains after program 


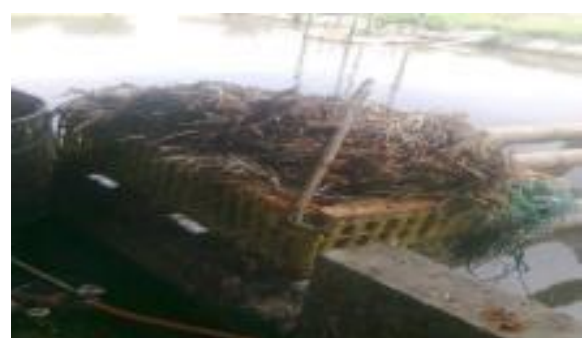

Figure 4. Waste slaughter before the program

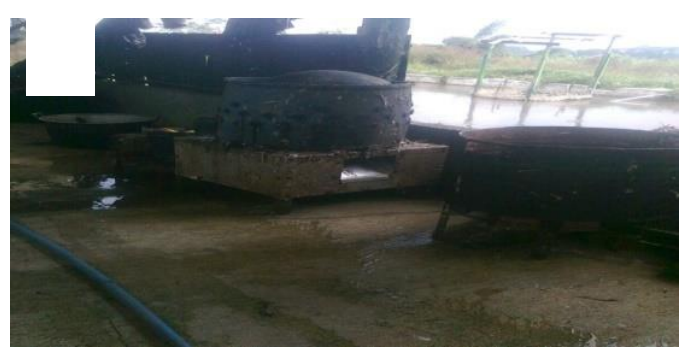

Figure 5. Waste slaughter after the program

a. Provide counseling utilization of waste chicken feathers for the communities around the slaughterhouse

This event was attended by 21 village cadres who are all employees of the cuts. Cutting employee usually works at night, and by noon they are unemployed (not working), other than that they are already accustomed to struggling with waste chicken feathers, so it is not awkward to plunge therein. It is very effective to supplement their income in particular and improve the welfare of rural communities Krasak in general. Program utilization of waste chicken feathers is preceded by a workshop waste processing chicken feathers into feather meal of chicken, then processing practices in small amounts and many, and the last workshop product packaging and marketing of chicken feather flour products, as well as the inauguration of a chicken feather meal processing unit. The average attendance of almost $100 \%$. Thus through the village cadres, the public has knowledge of the utilization of waste chicken feathers into products useful. The treatment process begins with washing the feathers and then drained. Furthermore DioPen until dry, and the latter ground.

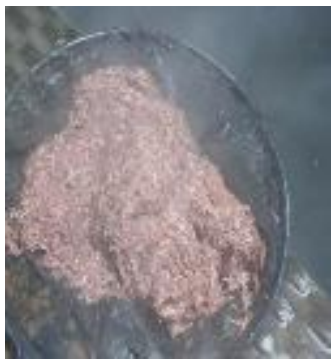

whased

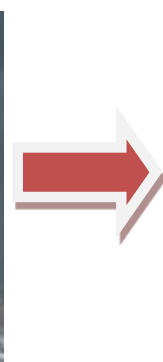

baked

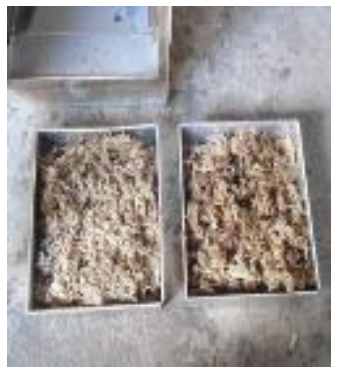

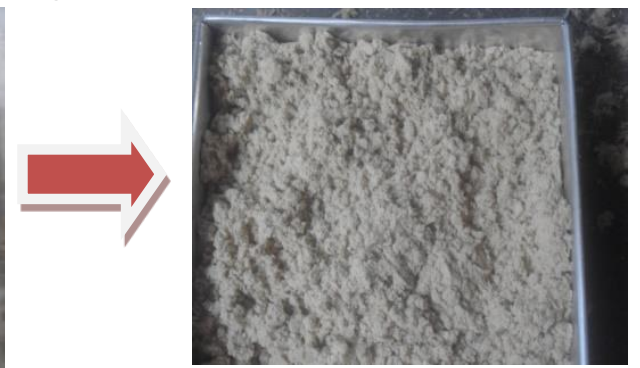

granded

Figure 6. The processing of chicken feather meal

b. The creation of a manufacturing unit of chicken feather meal as an alternative feed catfish with materials from waste chicken feathers

Chicken feather meal processing unit of waste chicken feathers is housed in the home village head for a while, so you can easily to monitoring. There are of granded machine, open presto, and the furnace stove. For streamline the functions of this unit, where the cuts are far from the location of the unit, for boiled and baked waste chicken feathers, henceforth telled to the processing unit. so it does not rot and pollute the environment. Hope for the future of society finally able to make the processing units of chicken feather meal, and more able to absorb labor. 


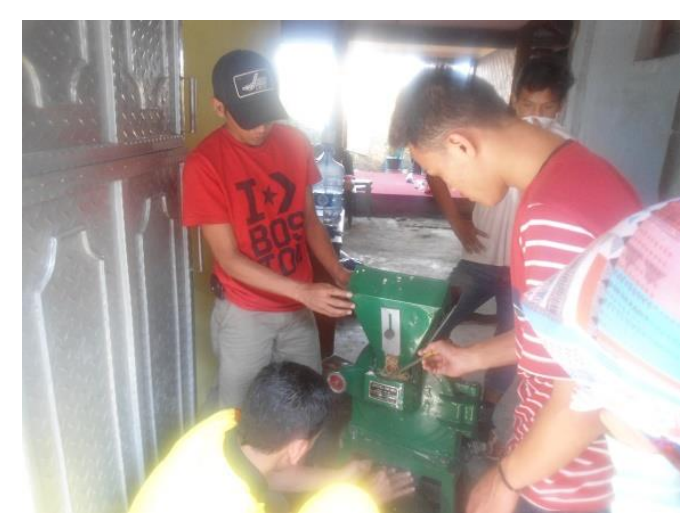

Figure 7. Chicken feather meal processing unit

c. Growth of New Business of Waste Utilization

Their chicken feather meal processing unit is a media and training facilities for the village cadres in processing and take a benefit of waste chicken feathers into feather meal of chicken. Team community service programs provide intensive assistance to village cadres really can treat waste chicken feathers into feather meal of chicken. After the workshop and training service program monitoring team for two times to make sure the trainees can make products chicken feather waste utilization activities, such as chicken feather meal and ensure the program actually runs. Monitoring is also carried out on a marketing program to the area Kertek village and kalikajar village, so that we can be sure the chicken feather meal product actually marketed. This chicken feather flour products in addition to animal feed mixes such as cows and goats, also could remedy poultry feed, chicken and return to the chicken. It is easier for marketing, because the cutting area Krasak quite a lot and need a lot of weekends to his chicken farm. Thus through this new establishment, the community around the cuts could increase the income of the family economy.

Chicken feather meal produced of approximately $10 \mathrm{~kg}$ per day. Fur waste was sold to the community around and outside the location of $4500 / \mathrm{kg}$. Gross earnings in the first week of Rp 270,000; for gas Rp. 20.000; and fuel of granded machine Rp. 20,000 with an average processing time per day 1 hour. Chicken feather meal that has been packaged is deposited in places of sale of animal feed, and partly taken by persons of telled broilers.

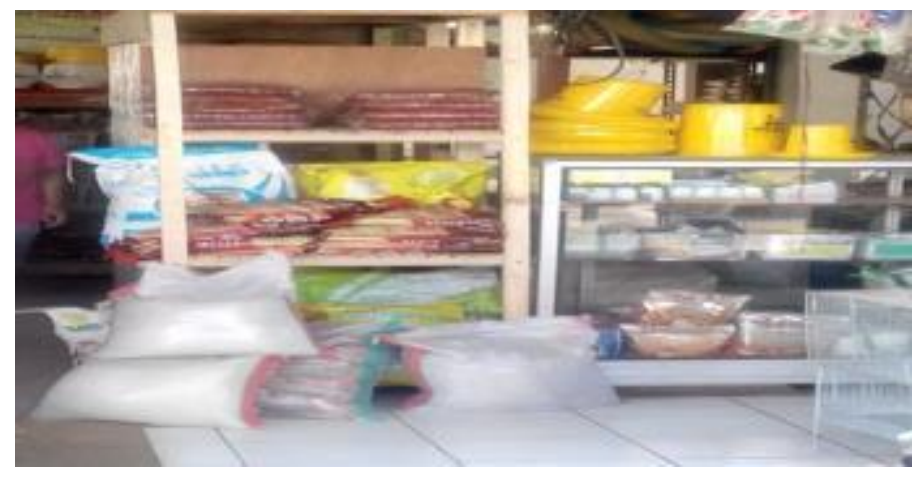

Figure 8. Marketing chicken feather flour products 
In order to increase the availability of animal feed quality, and support the improvement of livestock production to meet the demand for animal protein, and to improve national food security by increasing the population from better nutrition One technology alternatives to be able to utilize cassava as raw material for animal feed is to how to turn it into a quality product, namely chicken feather meal. Onggok an agroindustrial solid waste manufacture of tapioca flour that can be used as fermentation media as well as animal feed. Cassava can be used as a carbon source in a medium because it still contains a lot of starch $(75 \%)$ are not extracted, but lower crude protein content, namely, $1.04 \%$ out based on the dry matter. So that the necessary addition of other materials as a source of nitrogen which is indispensable for the growth of feed [8].

Quill is a livestock waste that can be used as feed material alternative sources of animal protein in the ration formulation chicken (poultry). This is because the feathers have a fairly high protein content [9], the crude protein chicken feather meal $86.5 \%$ and energy of metabolism 3,047 kcal / kg. Likewise, according to Rasyaf (1993), containing chicken feathers crude protein was as high as $82-91 \%$, much higher protein content than fishmeal [10].

When dlihat in terms of availability, chicken feather meal very potential as alternative feed ingredient in poultry rations. This is supported by a number of cuts of chicken continues to increase from year to year, causing the availability of waste chicken feathers continue to increase especially in rural Krasak. Likewise, when viewed from the protein content of chicken feathers potential then be used as an alternative feed source of animal protein substitute for fish meal because they contain a high enough protein and rich in essential amino acids. But as an alternative feed ingredients, chicken feather meal not only in terms of availability alone but the nutritional content whether support for use in poultry ration formulation widely.

As a raw material feed, feathers rarely used by poultry feed mill. Despite relatively high protein and rich in essential amino acids, but the problems are now a bona fide chicken feather meal inhibiting factors such as the content of the protein keratin fibers classified. High crude protein content in chicken feather meal was not followed by a high biological value. This causes the value of dry matter and organic matter on the low chicken feather meal. Values are low in starch digestibility chicken feather keratin caused by the content. Keratin is a protein that is rich in sulfur amino acid, cystine. Keratin is difficult to digest because the disulfide bonds formed between cysteine amino acids cause a protein is difficult to digest by the poultry, either by rumen microorganisms and proteolytic enzymes in the digestive tract after the rumen in ruminant livestock.

Keratin can be broken down through chemical reactions and enzymes, which in turn can be digested by trypsin and pepsin in the digestive tract. So that when the chicken feather meal is used as feed material source of protein, should be processed first need to improve digestibility. The biological value of chicken feather meal can be upgraded with a variety of processing and delivery of the correct treatment.

Chicken feather meal generated from this program for foodstuffs poultry and catfish are available in the form of a guaranteed product and a ready-made feather meal or 
feather meal that has been processed. Various studies in different parts of the world shows that feather meal can be used at a level of no more than $4 \%$ of the total ration formula without making poultry productivity slump. The better prepared, the better it becomes. More and more use this flour will only depress achievement poultry, reduced egg production and weight gain are also in decline [11]. As a food ingredient poultry and swine, feather meal this is not really exciting. The extent to which its use is dependent on the ability to process the feather meal.

Results Erpomen et al. (2005) rations treated with the composition as follows: $\mathrm{A}=$ ration without TBA (control), B = Replacement of $25 \%$ protein fish meal with TBA, C $=$ Replacement of $50 \%$ protein fish meal with TBA, $\mathrm{D}=$ Replacement of $75 \%$ protein fish meal with TBA, E = Replacement of $100 \%$ fish meal protein with TBA. The parameters observed during the study: feed consumption, body weight gain, feed convention. From the results of the phase I study it appears that there is no interaction $(\mathrm{P}>0.05)$ between the dose of $\mathrm{NaOH}$ with long steaming towards $\mathrm{BK}, \mathrm{PK}, \mathrm{LK}$ and steaming fermentation TBA provide a significant influence $(\mathrm{P}<0.05)$ against $\mathrm{BK}, \mathrm{PK}$, LK and protein digestibility (TBA). From the analysis of phase 2 showed that chicken feathers that have been treated in the Phase I give the effect of significantly different ( $P$ $<0.05$ ) on feed consumption, the United Nations and feed conversion. From the results of this study concluded that: concentration of $\mathrm{NaOH}$ and prolonged heating of the best was $0.2 \%$ with heating times of 90 minutes memeberikan highest protein digestibility of $45.02 \%$ and the lowest fat content rough and crude protein $13.37 \% 53.79 \%$, Feathers treated with $\mathrm{NaOH}$ can be used up to the level of $15 \%$ (75\% fish meal replacement) in broiler ration. It is seen from the feed intake, the UN, and the same feed conversion ration without feathers ayam.Jadi can be concluded that: concentration of $\mathrm{NaOH}$ and prolonged heating of the best was $0.2 \%$ with heating times of 90 minutes memeberikan highest protein digestibility of $45,02 \%$ and fat content of $13.37 \%$ and the lowest rude crude protein $53.79 \%$. Feathers treated with $\mathrm{NaOH}$ can be used up to the level of $15 \%$ (75\% fish meal replacement) in broiler ration. It is seen from the feed intake, the UN, and the same feed conversion ration without the feathers. The nutritional content of processed feather meal are listed in Table 1 below.

Table 1. Nutrient Flour Chicken Feathers

\begin{tabular}{llcr}
\hline \multicolumn{1}{c}{ nutrition } & \multicolumn{3}{c}{ Ingredients } \\
\hline Crude protein Crude Fiber & $85 \%$ & 0,3 & - \\
Ash & 3,0 & - & $3,5 \%$ \\
calium & 0,20 & - & $0,40 \%$ \\
phosphorus & 0,20 & - & $0,65 \%$ \\
Salt & $0,20 \%$ & & \\
\hline
\end{tabular}

Quill as waste or byproducts of the slaughterhouse (TPA) is plentiful and can be used as a source of protein feed and valued-added when processed into flour quill [13]. The exploitation and use of chicken feather meal as a component of protein food supplement ruminants has not been done. Chicken feather meal can be used as one component of 
animal feed as a source of dietary protein rurninansia maximum of $40 \%$. It is recommended that its use be done after going through a treatment process for bonding of cystine in chicken feathers could unravel. Utilization of chicken feather meal as a food ingredient ruminant livestock should be reserved for growing (f $10 \%$ protein in the ration).

So large and the benefits Flour chicken feathers, with a look at the nutritional content has not been a factor of success of this program can be run well. Need a lot to be disseminated to the public especially the owner of the farm, so that eventually the owners of the ranch stout that uses chicken feather meal as an alternative feed livestock.

\section{References}

[1] Miftah Fatmasari. 2010. "Instalasi Pengolahan Air Limbah Industri Farmasi Formulasi”. Tugas Akhir Tidak Dipublikasikan, Institut Pertanian Bogor

[2] Moses Laksono S. dan Mera Kariana. 2010. "Peningkatan Produktivitas dan Kinerja Lingkungan dengan Pendekatan Green Productivity Pada Rumah Pemotongan Ayam". Jurnal Fakultas Teknologi Industri, Institut Teknologi Sepuluh Nopember Surabaya,

[3] Nurtjahya, E. 2003. "Pemanfaatan Limbah Ternak Ruminansia untuk Mengurangi Pencemaran Lingkungan”. Makalah Pengantar Falsafah Sains (PPS702), Program Pasca Sarjana, Institut Pertanian Bogor

[4] Winiati P. Rahayu. 2008. "Penanganan Limbah Industri Pangan". http://www. foodreview.biz/login/preview.php?view\&id=33362.

[5] Iwan Berri Prima. 2002. "RPA Sebagai Bagian dari Kesmavet" . Jakarta : Majalah Poultry Indonesia

[6] Slamet Hartanto. 2008. Pengelolaan Sampah Berbasis Maslahah, Yokyakarta : Edite Pustaka

[7] Anonimus, 2003. Bulu Unggas Untuk Pakan Ruminansia. Warta Penelitian dan Pengembangan Pertanian. Volume 25 No. 6.

[8] Supratman w. 2011. Pemanfaatan Limbah Industri (Onggok) sebagai pakan ternak. http://livestock-livestock.blogspot.com/2011/06/pemanfaatan-limbahindustri-onggok.html. diakses 4 juni 2011.

[9] Murtidjo, B.A. 1995. Pedoman Meramu Pakan Unggas. Penerbit Kanisius. Yogyakarta.

[10] Rasyaf, M, 1993. Bahan Makanan Unggas di Indonesia. Penerbit Kanisius, Yogyakarta.

[11] Rasyaf, M, 1993. Bahan Makanan Unggas di Indonesia. Penerbit Kanisius, Yogyakarta.

[12] Pond,W.G and J.H. Manner. 1974. Swine Production in Temperate and Tropical Environments. W.H. Freman and Company. San Fransisco.

[13] Adiati, umi.dkk 2004.peluang Pemanfaatan Tepung Bulu Ayam Sebagai Bahan Pakan Ternak Ruminansia. Wartazoa vol. 14 no. 1 